SYLWIA MIKOLAJCZYK

DOROTA WEIGT

AGNIESZKA TOMKOWIAK

ZBIGNIEW BRODA

JAN BOCIANOWSKI

Uniwersytet Przyrodniczy w Poznaniu, Wydział Rolnictwa i Bioinżynierii,

Katedra Genetyki i Hodowli Roślin

Kierownik Tematu: dr inż. Sylwia Mikołajczyk Uniwersytet Przyrodniczy w Poznaniu, Katedra Genetyki

i Hodowli Roślin, ul. Dojazd 11,60-632 Poznań, tel. 61 8487719, e-mail: sylwia.mikolajczyk@up.poznan.pl

Prace zostały wykonane $w$ ramach badan podstawowych na rzecz postępu biologicznego $w$ produkcji roślinnej na podstawie decyzji Ministra Rolnictwa $i$ Rozwoju Wsi nr HOR.hn.802.16.2018, Zadanie 86.

\title{
Haploidyzacja żyta — diagnostyka molekularna oraz wpływ nanomolekuł na wspomaganie indukcji i regeneracji roślin w warunkach in vitro
}

\author{
Haploidization of the rye - the molecular diagnostics and the influence \\ of nanomolecules on supporting the induction and regeneration of plants \\ in in vitro conditions
}

Słowa kluczowe: androgeneza, kultury pylników, markery ISSR i RAPD, żyto

Zdolność do regenerowania form haploidalnych jest uwarunkowana genetycznie i powoduje silne zróżnicowanie w liczbie otrzymywanych roślin haploidalnych poszczególnych gatunków, a nawet genotypów tego samego gatunku. W pracach dotyczących kultur pylników i izolowanych mikrospor podkreślana jest konieczność poszukiwania nowych rozwiązań metodycznych niezbędnych dla przełamania braku zdolności regeneracyjnych u tzw. „opornych genotypów” (Shahinul Islam i Tuteja, 2012). Parametry odpowiedzi w kulturze pylników i izolowanych mikrospor są cechami ilościowymi kontrolowanymi przez geny jądrowe. Dla jęczmienia, owsa, pszenżyta i ryżu opisano markery oraz QTL powiązane z otrzymywaniem podwojonych haploidów (Chen i in., 2007; Kiviharju i in., 2004). Żyto jest gatunkiem, u którego prowadzono badania nad tłem genetycznym i QTL odpowiedzialnymi za odpowiedź w kulturach tkankowych — TCR tissue culture responce (Bolibok i in., 2006; Targońska i in., 2013). 
Do badań realizowanych $\mathrm{w}$ zadaniu $\mathrm{nr} 86$ wykorzystano materiały hodowlane o zróżnicowanym pochodzeniu oraz odmiany populacyjne z polskiej hodowli:

1. materiały hodowlane: NS16134/4, NS16135/1, NS16135/2, NS16137/7, NS16143/6, NS16144/1, NS16149/1, NS16153/2, NS16153/4, NS16156/4, S01175/17, S01176/17, S01179/17, S01185/17, S01216/17, S04284/17, S04298/17, S04319/17, S04329/17, S04351/17,

2. odmiany populacyjne: Antonińskie, Dańkowskie Amber, Dańkowskie Diament, Dańkowskie Skand, Dańkowskie Złote, Horyzo, Pastar, Piastowskie, Poznańskie, Rostockie, Słowiańskie.

\section{TEMAT BADAWCZY 1}

\section{Ocena polimorfizmu DNA i poszukiwanie markerów RAPD i ISSR powiązanych} z odpowiedzią żyta w kulturach pylników

Celem tematu badawczego 1 była ocena polimorfizmu DNA za pomocą markerów RAPD i ISSR oraz poszukiwanie markerów DNA powiązanych z efektywnością indukcji androgenezy i regeneracji roślin zielonych w kulturach pylników 31 genotypów żyta dla selekcji genotypów o wysokiej podatności na haploidyzację. Do analizy polimorfizmu DNA techniką RAPD (Random Amplified Polymorpfic DNA) zastosowano 30 starterów 10 nukleotydowych o losowej sekwencji, które wybrano na podstawie literatury i badań własnych. (Bolibok i in., 2007; Broda i in., 2008; Ćwiklińska i in., 2010; Kiviharju i in., 2004). Genomowy DNA został poddany również analizie ISSR (Inter Simple Sequence Repeats) z zastosowaniem 30 starterów reakcji wybranych na podstawie literatury (Bolibok i in., 2007; Hackauf i Wehling, 2002; Saal i Wricke, 1999).

W wyniku przetestowania 60 starterów (30 losowych dla RAPD i 30 o wybranej sekwencji nukleotydów dla ISSR) stwierdzono, że w reakcjach ISSR otrzymywano wyższą liczbę produktów, a wyniki analiz były bardziej powtarzalne. Podobieństwo genetyczne badanych 31 obiektów żyta mieściło się w zakresie od 5,3\% pomiędzy odmianą Horyzo a linią NS16153/2 do 85,7\% pomiędzy odmianą Antonińskie i Poznańskie. Analiza otrzymanych dendrogramów UPGMA (Unweighted Pair Group Method of Aritmetic Means) wykreślonych na podstawie podobieństwa genetycznego pozwoliła na wyróżnienie 5 głównych grup podobieństw pomiędzy badanymi 31 obiektami żyta (rys. 1 i 2 ). Otrzymane dendrogramy odzwierciedlały podobieństwo genetyczne badanych form $\mathrm{i}$ ich pochodzenie (rys. 1 i 2 ). 


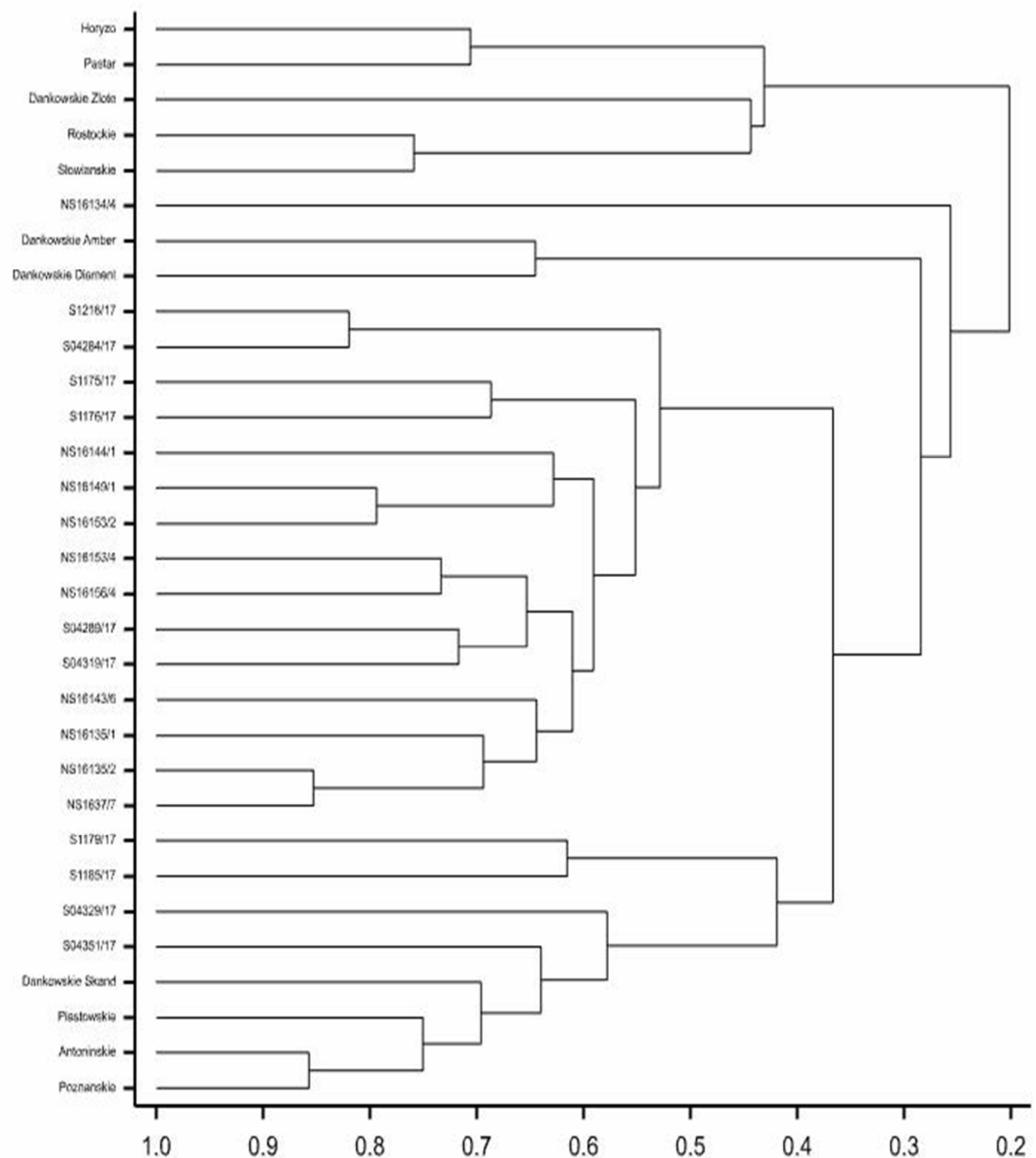

Rys. 1. Dendrogram przedstawiający podobieństwo genetyczne (GS - genetic similarity) pomiędzy badanymi genotypami żyta otrzymany na podstawie polimorfizmu DNA

z zastosowaniem 30 starterów RAPD 


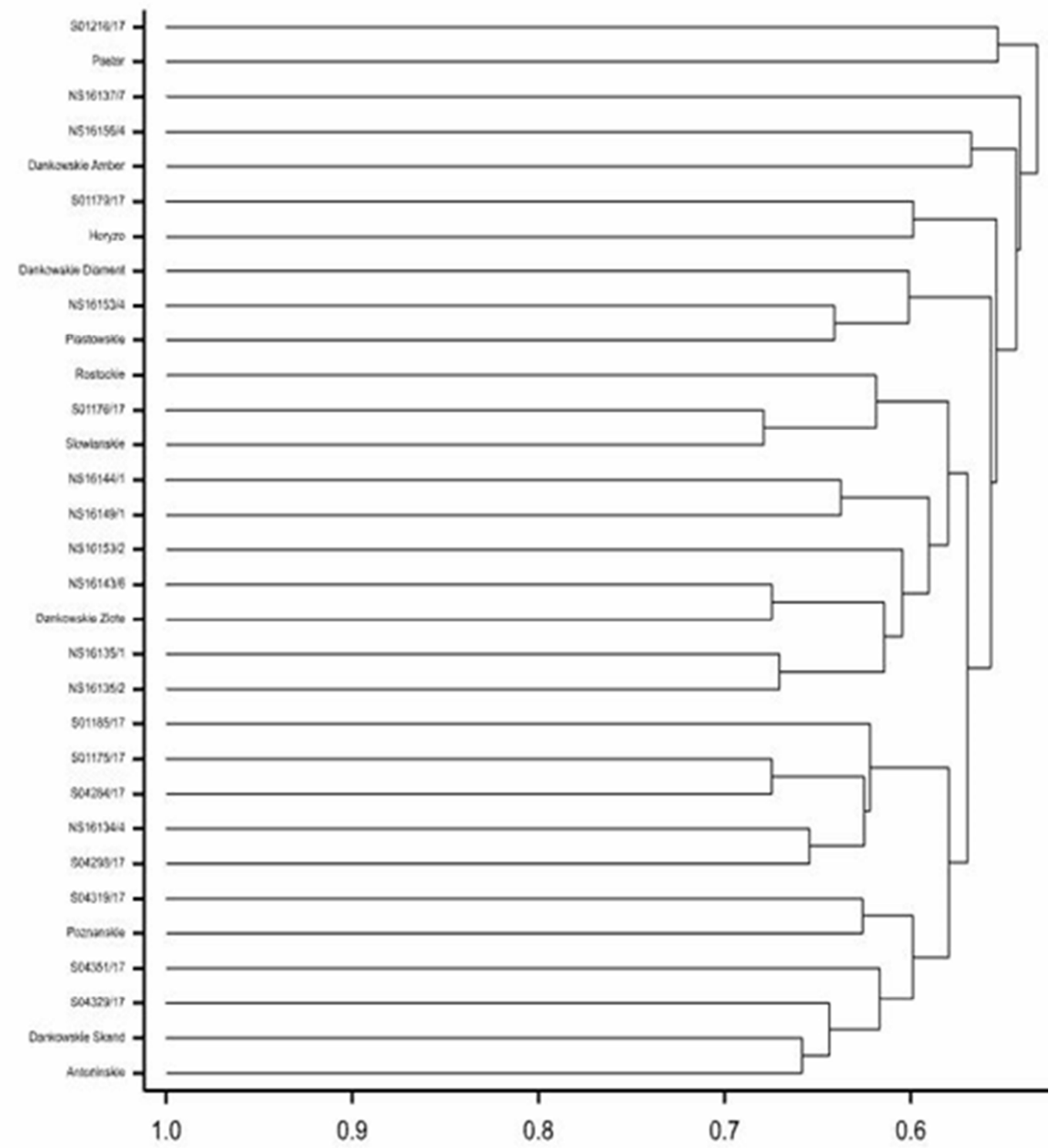

Rys. 2. Dendrogram przedstawiający podobieństwo genetyczne (GS - genetic similarity) pomiędzy badanymi genotypami żyta otrzymany na podstawie polimorfizmu DNA z zastosowaniem 30 starterów ISSR 


\section{TEMAT BADAWCZY 2}

\section{Weryfikacja opracowanej metodyki prowadzenia kultur pylników w aspekcie powtarzalności rezultatów i możliwości aplikacji dla szerokiego spectrum genotypów żyta}

Celem tematu badawczego 2 była ocena wpływu traktowania wstępnego kłosów żyta (temperatura $4^{\circ} \mathrm{C}$ ) oraz pożywki $\mathrm{C} 17$ i 190-2 na indukcję androgenezy i regenerację roślin w kulturach pylników żyta. W trakcie realizacji tematu badawczego 2 wyłożono 20000 pylników z 200 kłosów, w tym 10.000 z linii nonrestorerowych żyta i 10000 z mieszańców pokolenia S0 wyprowadzonych w ramach usług badawczych, z których otrzymano 87 kalusów mikrosporowych i 3 rośliny zielone. Średnia efektywność androgenezy na 100 wyłożonych pylników dla 20 badanych genotypów żyta, wynosiła $0,43 \%$, a efektywność regeneracji roślin $0,01 \%$. Kultury pylnikowe zakładano w 2 wariantach traktowania wstępnego kłosów i pylników żyta na 2 pożywkach indukujących androgenezę w kulturach pylników - pożywce C17 zawierającej mieszaninę auksyn $1 \mathrm{mg} / 2$,4-D i $1 \mathrm{mg} / 1$ dikamby i 190-2 z taką samą kombinacją auksyn. Najwyższą liczbę pylników tworzących struktury androgeniczne zaobserwowano dla genotypu S04351/17 - 32 kalusy mikrosporowe. W kulturach pylników tego genotypu najwyższą indukcję androgenezy zaobserwowano na pożywce $\mathrm{C} 17$ po 14 dniach przechowywania kłosów w temperaturze $4^{\circ} \mathrm{C}$. Najwyższą liczbę zregenerowanych roślin zaobserwowano dla genotypu S01175/17 — 2 rośliny po 21 dniach $w 4^{\circ} \mathrm{C}$ na pożywce $190-2$. Dla 10 badanych linii nonrestorerowych żyta nie zaobserwowano indukcji androgenezy i regeneracji roślin na obu pożywkach po traktowaniu założonych kultur pylnikowych temperaturą $4^{\circ} \mathrm{C}$ przez 21 dni.

Traktowanie ściętych kłosów żyta temperaturą $4^{\circ} \mathrm{C}$ przez 21 dni było najefektywniejsze dla indukcji androgenezy w kulturze pylników na pożywce C17 z mieszańców pokolenia S0. Indukcja androgenezy w kulturach pylników żyta była prawie dwukrotnie wyższa po 21 dniach $\mathrm{w} 4^{\circ} \mathrm{C}-46$ reagujących pylników niż po 14 dniach $\mathrm{w} 4^{\circ} \mathrm{C}-24$ reagujące pylniki mieszańców S0 żyta. Po traktowaniu kłosów temperaturą $4^{\circ} \mathrm{C}$ przez 21 dni zregenerowały 3 rośliny zielone w porównaniu z brakiem regeneracji roślin zielonych po chłodzeniu kłosów mieszańców S0 żyta przez 14 dni w $4^{\circ} \mathrm{C}$.

$\mathrm{Na}$ podstawie oceny efektywności indukcji androgenezy i regeneracji roślin w kulturach pylników 20 genotypów żyta stwierdzono, że traktowanie pylników temperaturą $4^{\circ} \mathrm{C}$ przez 21 dni wpłynęło inhibująco na analizowane parametry androgenezy dla linii nonrestorerowych żyta, które tworzyły struktury androgeniczne tylko na pożywce C17 po 14 dniach przechowywania kłosów w temperaturze $4^{\circ} \mathrm{C}$.

\section{LITERATURA}

Bolibok H., Gruszczyńska A., Hromada-Judycka A., Rakoczy-Trojanowska M. 2007. Identification of QTLs associated with the in vitro response of rye (Secale cereale L.). Cel. Mol. Biol. Lett. 12 (4): 523 - 35.

Bolibok H., Rakoczy-Trojanowska M., Wyrzykowska M., Radecka M., Orczyk W. 2006. Identification of microsatellite markers in the rye genome. Cel. Mol. Biol. Lett. 11: 291 - 298. 
Broda Z., Kurasiak-Popowska D., Kowalska A., Ćwiklińska A. 2008. Analiza podobieństwa genetycznego wybranych gatunków w rodzaju Secale. Biul. IHAR 247: 65 - 71.

Chen X. W., Cistué L., Munoz-Amatrian M., Sanz M., Romagosa I., Castillo A. M., Valles M. P. 2007. Genetic markers for doubled haploid response in barley. Euphytica 158: 287 - 294.

Ćwiklińska A., Broda Z., Bocianowski J., Dobrzycka A. 2010. The usefulness of RAPD and AFLP markers for determining genetic similarity in rye (Secale L.) species and subspecies. Acta Biol. Cracov. Bot.; 52 (1): $19-25$.

Hackauf B., Wehling P. 2002. Identyfication of microsalellite polymorphism in an expressed portion of the rye genome. Plant Breeding 121: $17-25$.

Kiviharju E., Laurila J., Lehtonen M., Tanhuanpää P., Manninen O. 2004. Anther culture properties of oat $\times$ wild red oat progenies and a search for RAPD markers associated with anther culture ability. Agricultural and Food Sci. 13: $151-162$.

Saal B., Wricke G. 1999. Development of simple sequence repeat markers in rye (Secale cereale L.). Genome. 42 (5): $964-72$.

Shahinul Islam S. M., Tuteja N. 2012. Enhancement of androgenesis by abiotic stress and other pretreatments in major crop species. Plant Science 182: $134-144$.

Targońska M., Hromada-Judycka A., Bolibok-Brągoszewska H., Rakoczy-Trojanowska M. 2013. The specificity and genetic background of the rye (Secale cereale L.) tissue culture response. Plant Cell Rep. 32: $1-9$. 